SPECIAL ARTICLE

\title{
Pattern of leprosy in Queensland, Australia, 1855-1990
}

\author{
G H REE \\ Division of Specialized Health Services, Department of Health, \\ 63-70 George Street, Brisbane 4000, PO Box 232, North Quay, \\ Queensland 4002, Australia
}

Accepted for publication 17 May 1991

\begin{abstract}
Summary Leprosy was first diagnosed in Queensland in 1855. From then until 1990, 929 patients with the disease were notified. The pattern of notification has varied with the passage of time, and with the changing pattern of migration into Queensland. In the early days, Chinese, Melanesians and Caucasians featured prominently. The first Aboriginal notification was in 1892. In the latter part of this century, significant numbers of Torres Strait Islanders and migrants from South East Asia have been recorded. Among Caucasians, the incidence peaked in the decade 1931-1940, although the prevalence rate in this population remains much higher than in Caucasians. The control of leprosy is at a high level in Queensland today, but there is a continuing low level of new case reporting, many of them imported.
\end{abstract}

\section{Introduction}

The origins of leprosy in Queensland are obscure. Ashburton Thompson, ${ }^{\prime}$ in 1897, listed all the cases recorded in the state from 1855 to 1895; he concluded that Chinese immigrants were responsible for the introduction of the disease. He also noted that many Melanesian-indentured labourers were suffering from the disease (but were not recorded as such) but did not attribute any epidemiologic role to this population. This early period also coincided with mass movements of other racial groups into Australia and Queensland. Significantly, the Chinese appeared to bear the brunt of responsibility for leprosy not only in Australia but also in other Western societies. ${ }^{2}$ Queensland responded to the perceived threat to public health with its own leprosy regulations in 1890 , followed by the Leprosy Act of 1892, which allowed for the compulsory notification and segregation of persons afflicted with the disease.

Some of the difficulties inherent in making a diagnosis of leprosy, and thus in defining the epidemiology of the condition, have been outlined previously. ${ }^{3,4}$ Traditionally, epidemiologic studies have tended to segregate migrants from analyses of endemic diseases. The State of Queensland was founded on migration, and migrants have played an important role in its development. Between 1873 and 1976, approximately 20,000 Chinese entered the State, largely to work in the gold fields. Starting in 1863, indentured labourers from neighbouring Melanesian Islands were imported to work in coastal sugar 
cane plantations. By 1883, an estimated 13,000 such labourers were working in Queensland. White settlers came in three great waves, between 1871 and 1890, between 1906 and 1930, and after the Second World War. The early white settlers were mainly from the British Isles, later they came from all over Europe. In the past 15 years, there has been increasing migration from South East Asia. All of these groups have contributed to the pattern of leprosy as seen in Queensland, and need to be considered in assessing epidemiologic trends.

Epidemiology is also concerned with the geographical distribution of disease. Studies in Norway, ${ }^{5}$ Portugal $^{6}$ and Louisiana ${ }^{7}$ (among some western countries), have described the limited geographical distribution of leprosy in these countries. Various explanations for this phenomenon have been offered. This area of study is particularly difficult for Queensland, and especially for the Aboriginal population. In 1897, a policy of 'removal' was instituted which encouraged the development of settlements-run either by religious organizations or Government agencies-in various parts of the State. ${ }^{8}$ While most numerous in the northern half of Queensland, where white population pressure was less extreme, the settlements did not necessarily reflect either the original pattern of population distribution, or its original tribal constitution.

The Torres Straits Islands are a group of islands lying between the northern tip of continental Australia and the island of New Guinea. Most of these islands are part of Australia, and are politically and administratively an integral part of the state of Queensland. There exist rights of passage from New Guinea to some of the islands without administrative control; this is likely to have an impact on the epidemiology of leprosy within that area. The population of the Islands is genetically heterogeneous, the original inhabitants having intermingled with Aboriginal people from Australia, Melanesians from New Guinea, Japanese pearl fishermen, Indonesian bêche de mer cullers and Europeans.

These confounding factors complicate any epidemiologic study, and allowance has to be made for these problems. This paper attempts to describe the situation in Queensland over the past one hundred and fifty years.

\section{Materials and methods}

For the period 1855 to 1890, the cases recorded by Ashburton Thompson were accepted as they stand. These cases were not included in the analysis. From 1890 onwards, leprosy was a notifiable disease. Basic demographic data usually included sex, age, race, country of origin, marital status and clinical type. Data from 1890 were entered into and manipulated on a custom PC database programmed in R base language. Analysis and graphic output were via the Microsoft chart package.

Queensland population figures and other demographic details were obtained from standard texts. Average annual incidence rates were calculated for each decade as the number of new cases occurring in that decade $\times 100,000$ divided by the mid-decade population $\times 10$ (for years of observation): and an average incidence rate for the whole period of observation was derived from the mean population through the study period.

Aboriginal populations were not officially numbered until the census of 1967. Rates for this population were derived from Queensland statistical texts and extrapolated backwards. The results of bacteriological investigations are included in some notifica- 
tions. Because of difficulties in comparing clinical classifications from the distant past with the more modern Ridley-Jopling classifications (see Irgens ${ }^{5}$ for a discussion of this), when possible, patients have been classified as multibacillary or paucibacillary, based on the presence of Mycobacterium leprae in material from the patients. Clearly in the early stages of the epidemic, many patients were not smeared, and classification for these patients is difficult. Statistical analysis included standard $\chi^{2}$ tests, tests for coefficients of correlation, and Student ' $t$ ' tests for differences between means.

\section{Results}

Between 1855 and 1890, 30 cases of leprosy were recorded. From 1891 to 1990, a further 899 patients were notified; these comprised 375 Aborigines, 293 Caucasians (of whom 179 were born in Queensland) and 231 others. The change in ethnic origin of the patients, 1851-1990, is shown in Figure 1. For 43 patients, the data of diagnosis were not recorded.

\section{CAUCASIANS}

The case detection rate for Caucasians peaked in the decade 1901 to 1910 and has declined ever since. The pattern is similar for both males and females (Figure 2). The sex ratio shows a male preponderance in all decades except the last. The excess of males is not
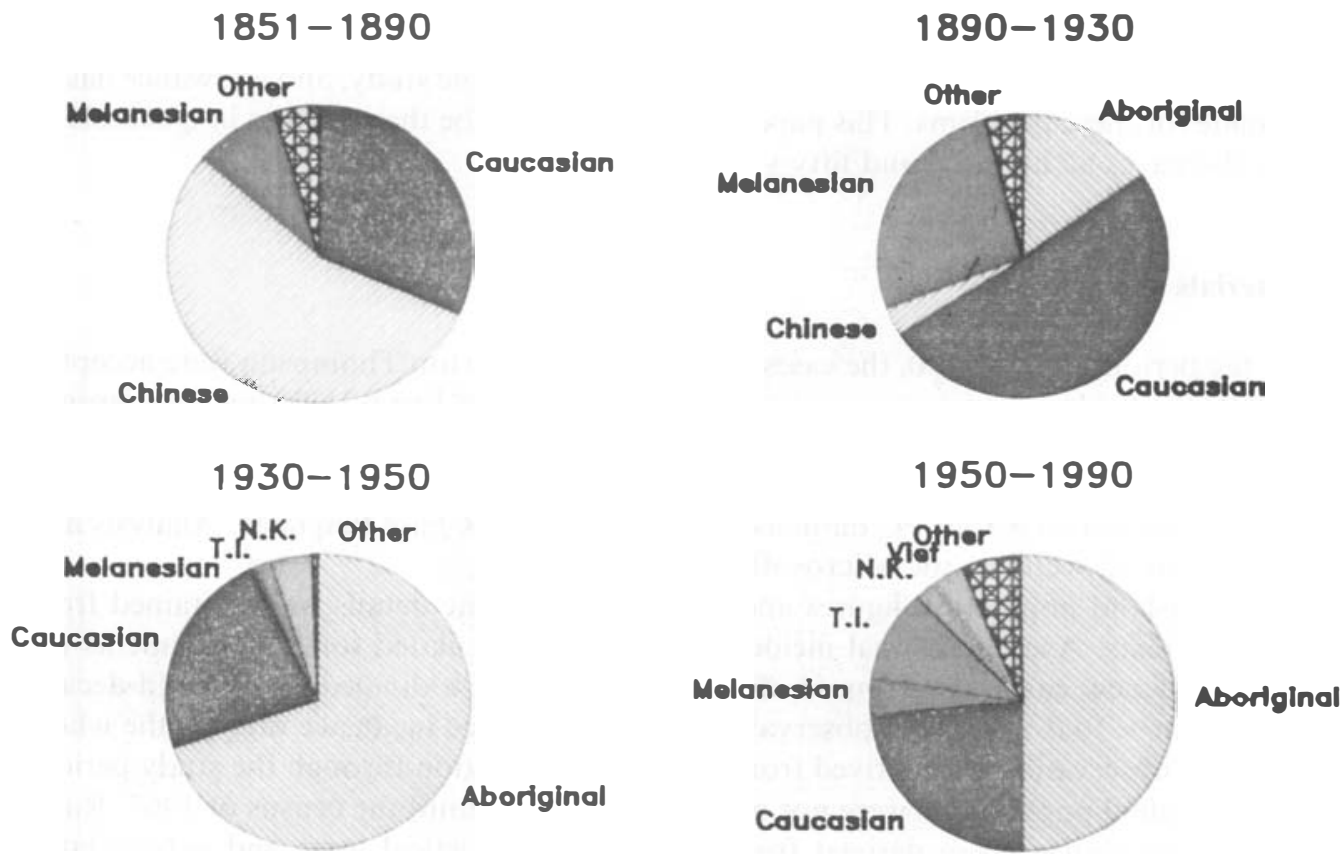

Figure 1. Leprosy cases by race, Queensland. 


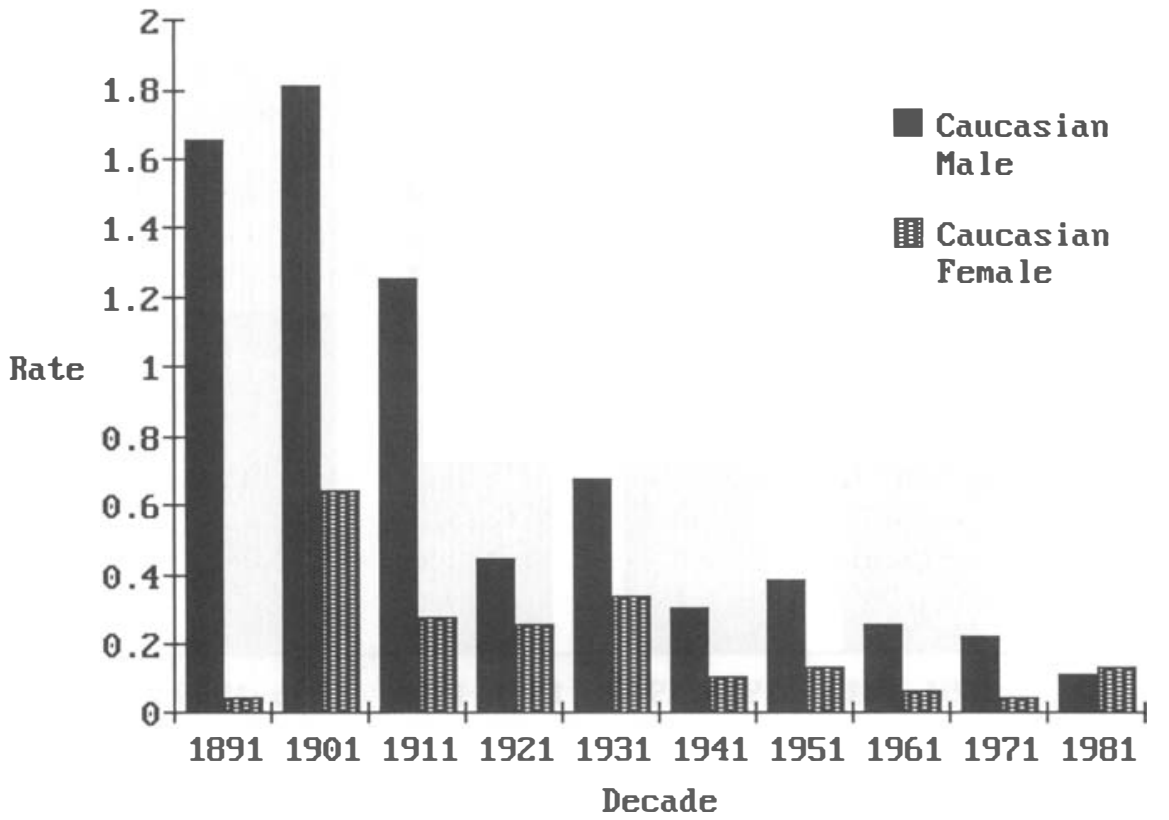

Figure 2. Caucasian annual leprosy rate per 100,000 by decade.

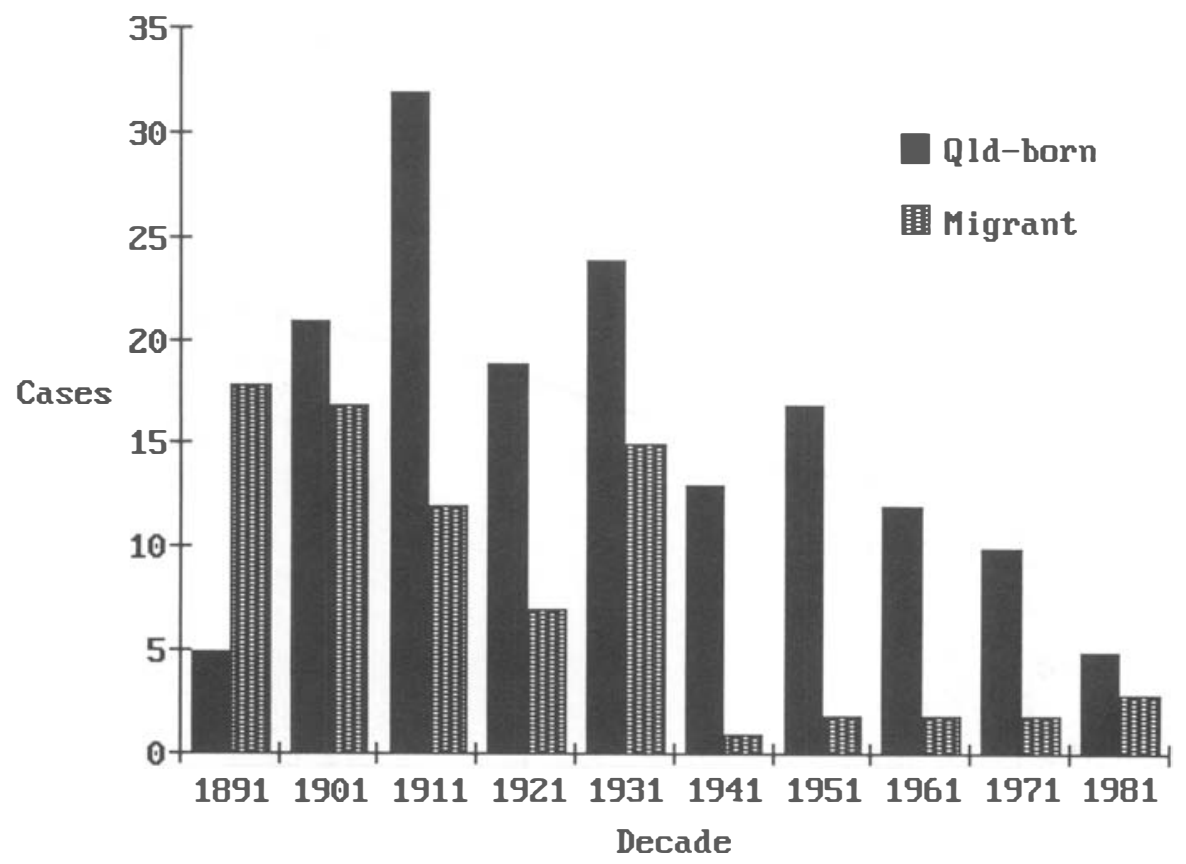

Figure 3. Caucasians. Leprosy cases by place of birth. 


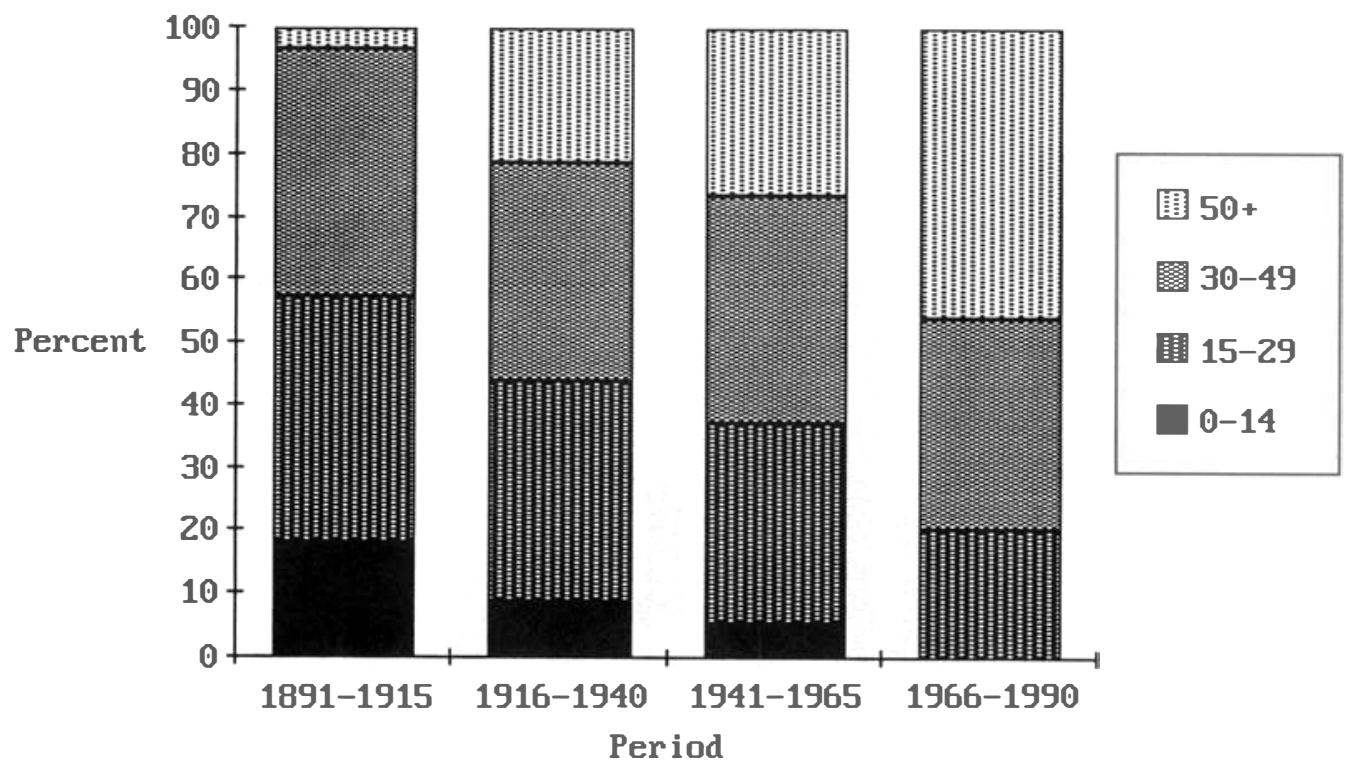

Figure 5. Age distribution of native male Caucasians by year of diagnosis.

related to an excess in male migrants, since the sex ratio is not significantly different between migrants and Queensland-born Caucasians.

In the decades 1891 to 1920, many of the Caucasians were migrants (Figure 3), $61 \%$ of whom originated in the British Isles. The average age of the migrants at the time of diagnosis was significantly greater than that of the Queensland-born Caucasians

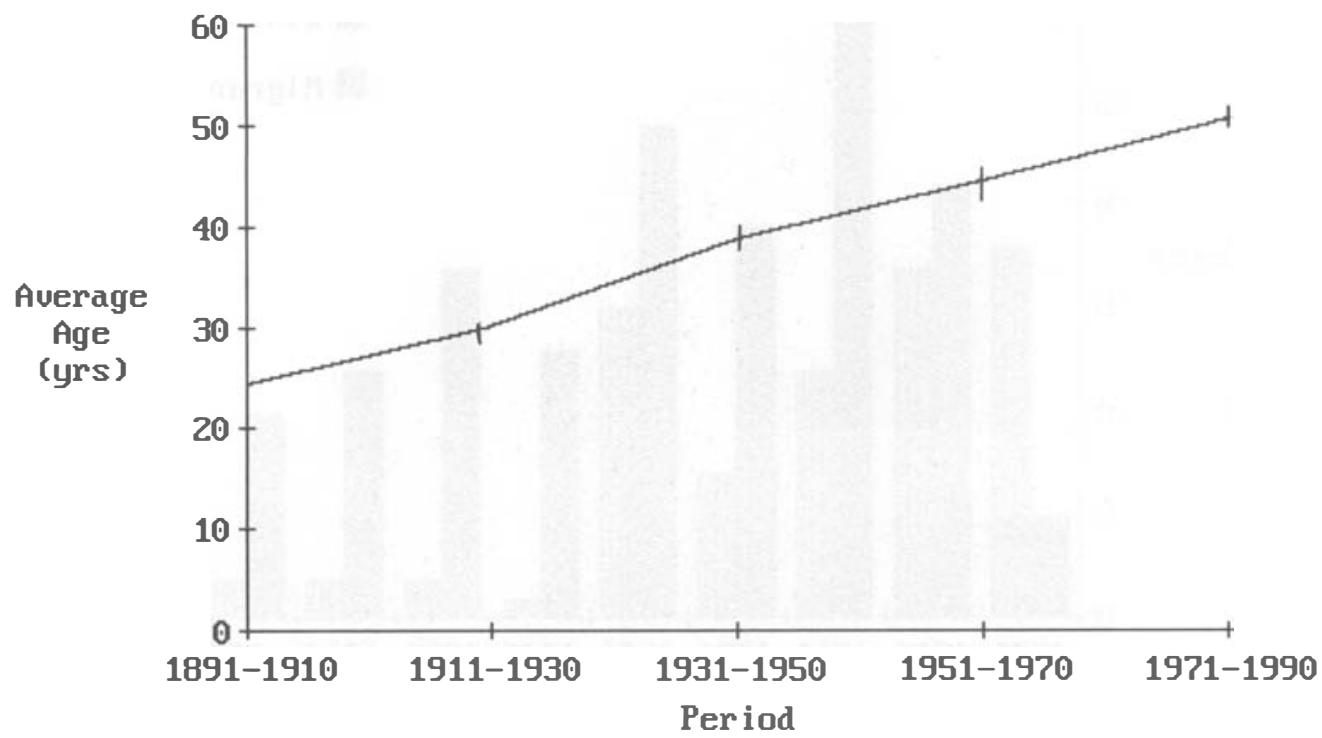

Figure 4. Leprosy cases. Age at diagnosis, Queensland-born male Caucasians. 
$(52 \cdot 2 \pm 13 \cdot 3$ years $v s 28 \cdot 2 \pm 14 \cdot 1$ years (mean $\pm \mathrm{SD}), P<0 \cdot 001)$. The migrants were, on average, $21 \cdot 3 \pm 10 \cdot 8$ years of age on arrival in Queensland. Excluding Caucasian migrants from the analysis, the mean age at the time of diagnosis has gradually increased with time, a trend which is highly significant $(r=0.998, P<0.001)$ (Figure 4$)$. This change is caused by a fall in the number of young people, and an increase in the number of older persons being diagnosed with the disease (Figure 5). Over the past one hundred years, the burden of leprosy has fallen on the age group 30-39, with the lowest average incidence in the age group 0-19 (Figure 5).

The average incidence is highest in the coastal, wet areas of Queensland (Figure 6). The dry, western areas of the state are less affected, but this may reflect not only total population in those divisions (which are small), but also relative population density: there is a significant correlation between population density/square-kilometre in the various divisions and the average case detection rate $(r=0.67, P<0.05)$.

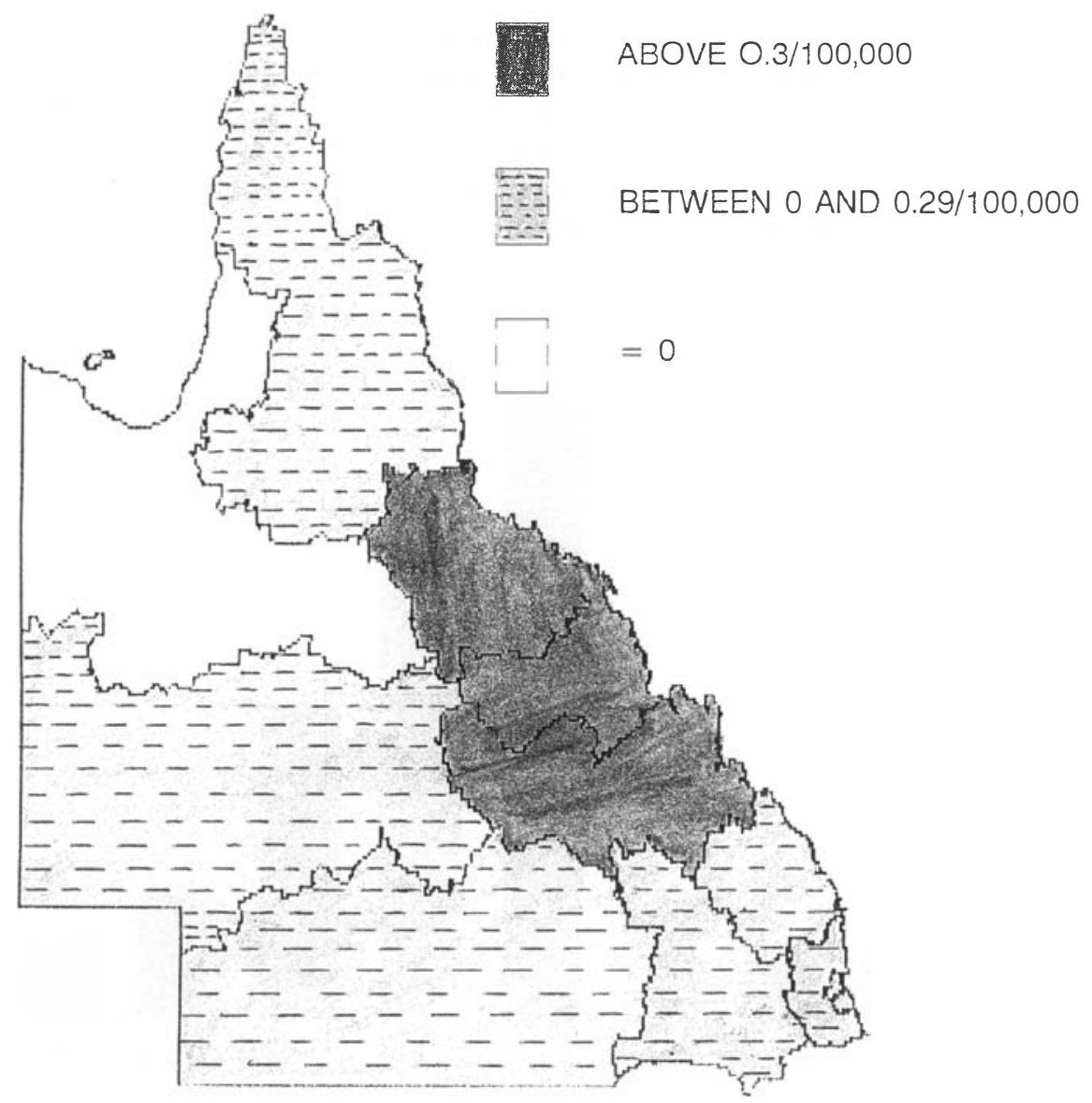

Figure 6. Queensland Statistical Divisions average incidence rate, Caucasians. 


\section{TORRES STRAIT ISLANDERS}

The Islanders are a genetically heterogeneous group of people living on small, scattered islands between the northern tip of continental Australia and the island of New Guinea. Thirty-two cases of leprosy were recorded in this population between 1931 and 1990, of whom more than half were diagnosed in the past 15 years.

The population of the Torres Strait Islands in 1971 was 7508 (of whom 3607 were male). The average incidence rate for the past 40 years (which includes all but 4 patients) was, therefore, $9 \cdot 3 / 100,000$ (11.8 for males, and $6 \cdot 4$ for females, giving a sex ratio of $173: 100)$.

\section{ABORIGINES}

The first recorded case of leprosy in a Queensland Aborigine was in 1892. A gradual increase in incidence rates led to a peak in the decade 1931 to 1940, followed by a sustained fall since then (Figure 7).

The sex ratio, based on notification numbers and not incidence rates, has varied widely from decade to decade, and averages at 171.4 males to 100 females. The ages for the Aboriginal patients were unreliable. For 74 (19.8\%) no ages were recorded. For the remainder, an excess of ages ending in 0 or 5 was recorded. There were $19(5 \cdot 1 \%)$ patients for whom the geographical origin was not recorded, of the remaining 355, $129(36 \cdot 3 \%)$ were from settlements, the others from non-settlement areas.

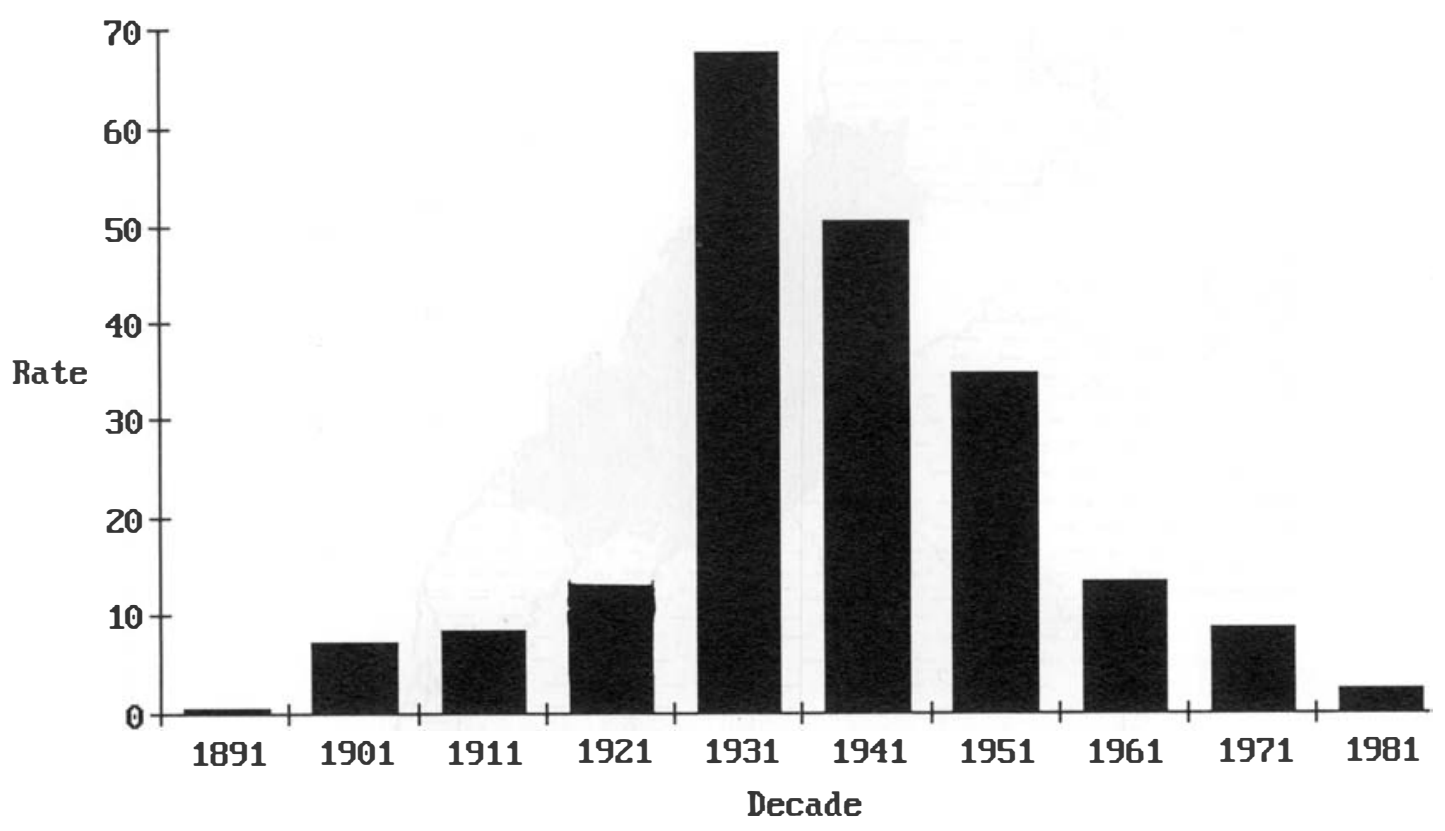

Figure 7. Aboriginal leprosy rate per 100,000 by decade. 


\section{MIGRANTS}

Only 11 Chinese patients were recorded after the introduction of the Leprosy Regulations, 9 of whom were diagnosed between 1897 and 1912. The remaining 2 were recent migrants. 92 Melanesians were registered, 77 of whom were indentured labourers diagnosed between 1892 and 1923. Of the 114 Caucasian migrants, 47 were from other Australian States, of the 67 from outside the continent, 43 (64.2\%) were from the British Isles, $79 \%$ of whom were diagnosed prior to 1930 . Of the 24 migrants from other

Table 1. Bacteriologic classification within different periods of time (No. (\%))

\begin{tabular}{lcccc}
\hline Period & $1891-1920$ & $1921-40$ & $1941-90$ & Total \\
\hline Paucibacillary & $5(1 \cdot 8)$ & $7(3 \cdot 6)$ & $101(3 \cdot 6)$ & 113 \\
Multibacillary & $30(10 \cdot 9)$ & $128(66 \cdot 8)$ & $226(58 \cdot 4)$ & 385 \\
Not done/reported & $239(87 \cdot 2)$ & $57(29 \cdot 5)$ & $60(15 \cdot 1)$ & 356 \\
\cline { 2 - 5 } & 274 & 193 & 387 & $854^{*}$ \\
\hline
\end{tabular}

* There were 43 patients for whom no clinical data are given.

Table 2

\begin{tabular}{|c|c|c|c|c|c|c|c|c|}
\hline & I & TT & BT & $\mathrm{BB}$ & $\mathrm{BL}$ & LL & PN & Total \\
\hline \multicolumn{9}{|l|}{ Causasian } \\
\hline $\mathrm{M}$ & - & 7 & 1 & 4 & 1 & 28 & 4 & 45 \\
\hline $\mathrm{F}$ & 1 & 4 & - & 2 & 1 & 5 & 2 & 15 \\
\hline \multicolumn{9}{|l|}{ Aborigine } \\
\hline $\mathrm{M}$ & - & 13 & 1 & 2 & 5 & 36 & 4 & 61 \\
\hline $\mathrm{F}$ & - & 9 & - & 6 & 1 & 21 & - & 7 \\
\hline \multicolumn{9}{|l|}{ Torres St. } \\
\hline M & - & 2 & 1 & 2 & 3 & - & 1 & 9 \\
\hline $\mathrm{F}$ & - & 4 & - & 1 & - & 1 & 2 & 8 \\
\hline \multicolumn{9}{|l|}{ Vietnamese } \\
\hline $\mathbf{M}$ & - & 2 & 1 & 1 & - & - & 1 & 5 \\
\hline $\mathrm{F}$ & - & 1 & 1 & 1 & 2 & & - & 5 \\
\hline \multicolumn{9}{|l|}{ PNG } \\
\hline $\mathrm{M}$ & - & 1 & - & - & 1 & 2 & - & 4 \\
\hline $\mathrm{F}$ & - & - & 1 & 1 & - & 1 & - & 3 \\
\hline \multicolumn{9}{|l|}{ Others* } \\
\hline $\mathbf{M}$ & - & 1 & 1 & 1 & - & 2 & - & 5 \\
\hline $\mathrm{F}$ & 1 & 4 & 1 & - & - & - & - & 6 \\
\hline \multicolumn{9}{|l|}{ Total } \\
\hline $\mathbf{M}$ & - & 25 & 5 & 10 & 10 & 68 & 10 & 131 \\
\hline $\mathrm{F}$ & 2 & 22 & 2 & 11 & 2 & 28 & 4 & 72 \\
\hline Grand total & 2 & 47 & 7 & 21 & 12 & 96 & 14 & 203 \\
\hline
\end{tabular}

*Includes: Indians, Indonesians, Chinese, Fijians, Laotian, Filipinos, El Salvadorans, Thai. 
European countries, 50\% were diagnosed before 1930. Between 1976 and the end of 1990 , 15 patients from South East Asia were notified. During the last decade, migrants from South East Asia represented $22 \%$ of the notifications.

\section{BACTERIOLOGY}

The first recorded bacteriological notification was made in 1892, a Melanesian male with nodular disease. For the first 30 years the majority of patients of all racial groups did not have bacteriology performed, or, if it was performed, the results were not recorded. That situation changed subsequently (Table 1).

\section{THE PRESENT SITUATION}

There are at present 203 patients on the leprosy register; all but 9 (2 Torres Strait Islanders, 2 Vietnamese and 5 Aboriginal patients) are considered to be inactive. The distribution of these 203 cases by ethnic origin and clinical type is shown in Table 2 .

\section{Discussion}

In historical studies, it is likely that many cases of leprosy (and especially minor tuberculoid cases) are either missed, not diagnosed, or not notified. The notifications therefore are of ten biased towards patients with more severe disease, or those with smear positivity who represent a public health danger. That this occurred in Queensland is suggested by the very high numbers of patients with bacteriologically positive lesions. Most authors emphasize the year of onset rather than the year of diagnosis, as there are often significant delays in reaching a diagnosis - especially where the disease is rare because it is newly introduced, or declining. However, this was not possible for this study as the information was not available.

It seems likely from the pattern of leprosy in Aboriginal people that the disease was introduced into Queensland-what the ethnic origin or origins of those responsible was is impossible to tell at this stage-what is clear however, is that in both Caucasians and Aborigines, leprosy came, peaked, and has been in decline now for a number of decades; whether this decline was the result of forced isolation into leprosaria (legislated by the Leprosy Act of 1892), or of socioeconomic change, or a combination of these effects, or other effects, is uncertain. Enforced isolation for Caucasians ceased in 1963, and clearly there has been no resurgence of disease since that date. Antimycobacterial treatment may have hastened the decline, but did not start it. The trend for an increasing age at onset with declining incidence has been noted in previous studies. ${ }^{5,6}$ Whether this represents an increase in incubation periods, or a postponement of infection to a higher age, is uncertain.

Comparing clinical types of disease over relatively long periods of time is hazardousdefinitions and classifications change with time, and it is impossible to state whether a patient diagnosed as having 'mixed leprosy' in 1890 is the same as a person with borderline today. ${ }^{5}$ The bacteriologic status is perhaps more instructive-in the period 1921-40, when bacteriological investigation was (almost) routinely performed, the majority of notified patients were multibacillary - in the last 50 years however, that 
situation has changed, with a third of notified patients in whom bascteriology was performed being paucibacillary. Most authors agree that paucibacillary disease is more common than multibacillary; in the remarkable epidemic in Nauru, ${ }^{9}$ the majority of cases were described as maculo-anaesthetic in whom bacteriologic examinations were usually negative. Clearly in Queensland, large numbers of patients with paucibacillary disease were either misdiagnosed, not notified, or ignored as of no epidemiologic significance.

Migration has played an important role in the development of the State: it is, however, unlikely that new migrants from leprosy-endemic areas will be able to re-introduce the disease into the autochthonous population. Studies in Britain and other countries have shown that secondary cases are exceedingly rare after the disease has spontaneously declined.

There is a pronounced male preponderance in this study for both Caucasian and Aboriginal patients. The sex ratio is often higher in lepromatous patients, who are probably over-represented, and there are remarkably few children (in whom the sex ratio tends to be more equal). There is no definite trend to a decline in the sex ratio with the decline in the endemicity of the disease, as has been reported in some studies.

The situation in Queensland has been unusual from the large ethnic variations which have contributed to the epidemiology of the disease; that there has been a significant decline is indisputable, and it is hoped that continuing surveillance will ensure that no resurgence occurs.

\section{Acknowledgments}

I am grateful to the Director-General, Health and Medical Services, for permission to publish this paper; to Dr A M Patel for helpful comments; to Ms L Hansson for endless patience in preparing the manuscript; and to $\mathrm{Mr}$ M Kanowski for the graphics.

\section{Ref erences}

1 Ashburton Thompson J. A contribution to the history of leprosy in Australia. London: The New Sydenham Society, 1897.

2 Gussow Z, Tracy GS. Stigma and the leprosy phenomenon: the social history of disease in the nineteenth and twentieth centuries. Int J Lepr, 1969; (? details).

${ }^{3}$ Fine PEM. Problems in the collection and analysis of data in leprosy studies. Lepr Rev, 1981; 52: Suppl 1, 197-206.

4 Newell KW. An epidemiologist's view of leprosy. Bull Wld Hlth Org, 1966; 34: 827-57.

5 Irgens LM. Leprosy in Norway. Lepr Rev, 1980; 51: Suppl 1, 1-130.

${ }^{6}$ Irgens LM, Melo Caeino F, Lechat MF. Leprosy in Portugal 1946-80: epidemiologic patterns observed during declining incidence rates. Lepr Rev, 1990; 61: 32-49.

7 Feldman RA. Sturdivant M. Leprosy in Louisiana 1855-1970. Amer J Epid, 1975; 102: 303-10.

8 Long JPM. Aboriginal settlements: a survey of institutional communities in eastern Australia. Australian National University Press, Canberra, 1970.

9 Wade HW, Ledowsky V. The leprosy epidemic at Nauru: a review. Int J Lepr, 1952; 20: 1-29. 


\section{Evolution de la lèpre dans le Queensland, en Australie, de 1855 à 1990}

\section{G H REE}

Résumé C'est en 1855 que la lèpre fut diagnostiquée pour la première fois a u Queensland. Depuis cette date jusqu'à 1990, 929 cas de lépreux furent déclarés. Le profil de la déclaration s'est modifié avec le temps et avec l'évolution de la migration au Queensland. Au début, il y avait un grand nombre de Chinois, Mélanésiens et d'hommes de race blanche. La première déclaration parmi les Aborigènes date de 1892. Au vingtième siècle, au cours des dernières années, un grand nombre de cas ont été rapportés chez les habitants des Iles Torres Strait et chez les émigrants du Sud-Est asiatique. Parmi les blancs, l'incidence a atteint son maximum au cours des années 1930 à 1940 bien que le taux de prévalence dans la population du Sud Est asiatique reste beaucoup plus élevé que celui de la race blanche. Le contrôle actuel de la lèpre est très stricte au Queensland mais on continue à rapporter un petit nombre de nouveux cas, en particulier parmi les immigrants.

\section{La distribucion de la lepra en Queensland, Australia, 1855-1990}

\section{G H REE}

Resumen La lepra fue diagnosticado por primera vez en Queensland en 1855. Desde entonces hasta 1990, han sido notificados 929 pacientes. La distribución de la notificación ha variado con el paso del tiempo, y según el cambio de migración en Queensland. En los primeros días, se destacaban los Chinos, Melanesios y Caucásicos. La primera notificación de un aborigen fue en 1892. A fines de este siglo se han registrado números significativos de isleños de Torres Strait e inmigrantes del sudeste de Asia. Entre los Caucásicos, la incidencia alcanzó un pico en la década 1931-40, aunque el nivel que prevalece en esta populación continúa más elevada que la de los Caucásicos. Se mantiene un nivel muy elevado de control de la lepra en Queensland hoy en dia, pero persiste un nivel ba jo de registraciones de casos nuevos, muchos de ellos importados. 